Fecha de recepción: marzo 2021 Fecha de aprobación: abril 2021 Fecha publicación: mayo 2021

\section{Defining Design for Sustainability and Conservation Mindsets}

Gabriela N. Baron ${ }^{(1)}$ and

Nadereh Ghelich Khani ${ }^{(2)}$

\begin{abstract}
Our planet is currently facing an unprecedented state of emergency concerning environmental depletion that has brought forth consequences such as biodiversity loss, climate change, and the rise of sea levels. These urgent, global challenges require new paradigms of being, relating to each other, and doing that operate from a foundational level (mental models), through a relational level (social connections, interdisciplinarity), and into a practice level (technical solutions).

Design for Conservation ${ }^{1}$ (D4C) is a methodological toolkit that environmental conservation groups can use to maximize innovation outcomes and ensure effective, sustainable, transformative change. In this paper, we present the rationale behind the mindsets that intend to set foundational attitudes when following a D4C approach. We also discuss the role of empathy, which is a fundamental aspect of the Design Thinking approach and it is also central to the D4C methodology as the main ability for the reconnection stage.

Mental models help us simplify complexity, understand why we consider some things more relevant than others, and influence our decisions. In general, contemporary designer mindsets promote openness and a positive attitude through empathy, collaboration, creativity, error-friendliness, iteration, ambiguity, amongst others. While these mindsets have proven to be very useful in a market-led context, they are insufficient when designing for sustainability and environmental conservation purposes. Design for Conservation requires a radical systemic shift that challenges the current notions of value, success, health and wellbeing, that cannot be achieved following market-led mental models.

Therefore, we established the following hypothesis: "through the use of bio-inspiration, we can identify general principles that govern people and natural systems alike and use them as a basis for defining mental models." The result of this analysis led to the definition of 7 interconnected mental models that consider humans as part of a complex ecosystem: Honest, Positive, Humble, Balanced, Relative, Systemic, and Cyclic.
\end{abstract}

Keywords: Mindsets - Mental Models - Design for Conservation - D4C - Design for Sustainability - Biomimicry - Transformative change - Systems thinking - Regenerative Design.

[Abstracts in spanish and portuguese at pages 150-151]

(1) Gabriela Nuri Baron by University of Auckland, New Zealand. Gabriela N. Baron is a Design academic, lecturer and researcher currently working at the University of Auckland. She specialises in Design strategy at the intersection between people, their communities 
and their natural environment. She has been working in the areas of Design for Conservation, Sustainability and Social Innovation for $15+$ years. Gabriela graduated as an Industrial Designer in Argentina and after working as an independent contractor she got a full grant to pursue a specialising master in Product-Service System Design at Politécnico di Milano in Italy. After gaining experience in Italy she was awarded a full time research grant to pursue a PhD in Environmental/Civil Engineering. Her unique study path has led her to follow a collaborative, interdisciplinary and systemic approach to addressing complex, global problems. Gabriela has been an educator and researcher in Argentina, Italy and New Zealand. As part of her teaching and research, she has developed highly visual tools that enable collaborative problem solving. She is currently developing the "Design for Conservation" methodology which explores alternative collaborative models around grassroots environmental conservation, as a decolonised approach that shed light on new ways of impact assessment that are closer to the people and their land (www.design4conservation.com).

(2) Nadereh Ghelich Khani, Ministry of Justice, New Zealand. Nadereh is originally from Iran and moved to New Zealand in 2007. Her university educational background is in science including an honours degree in physics and a Postgraduate Diploma in science and technology from Massey University, New Zealand. She has been working as a senior service designer and design lead for several governmental agencies for the last few years. Her professional development training covers the areas of innovation design, strategy, leadership, business analysis, agile mastery, design thinking, system thinking, data visualisation, data analysis and entrepreneurship.She has participated and mentored in a number of 'Start-up weekends', 'Hackathons' 'Design Jam' and 'Gov-hack' in Wellington, New Zealand. She has stabilised and run two businesses including School of Design Thinking Ltd. Nadereh is currently an independent researcher and speaker on the topic of empathy as a social cognitive theory. She is in the process of applying for $\mathrm{PhD}$ and exploring Design Thinking even further.

\section{Introduction}

\section{Mental Models and their importance for transformative innovation}

"We cannot solve problems with the same thinking we used when we created them," This famous quote allegedly coined by Albert Einstein ${ }^{2}$ summarizes the importance of working at the mindsets or mental models ${ }^{3}$ level when designing to regenerate our natural environment. Gaining a better understanding of how mental models internally represent complex, dynamic systems and how these representations change over time will allow us to develop mechanisms to enhance effective management and use of natural resources (Jones et al., 2011). 
The concept of mental models was originally coined by psychologist Craik (1943) to explain a set of mental attitudes or dispositions that predetermine how we understand the world. Not only do they shape what we think and how we know, but they shape the connections and opportunities that we see.

In line with this, Kania et al. (2018) state that conditions holding human systems in place are structured within three levels of change, from structural to transformational, the importance of working at the mindsets level is fundamental for ensuring lasting change.

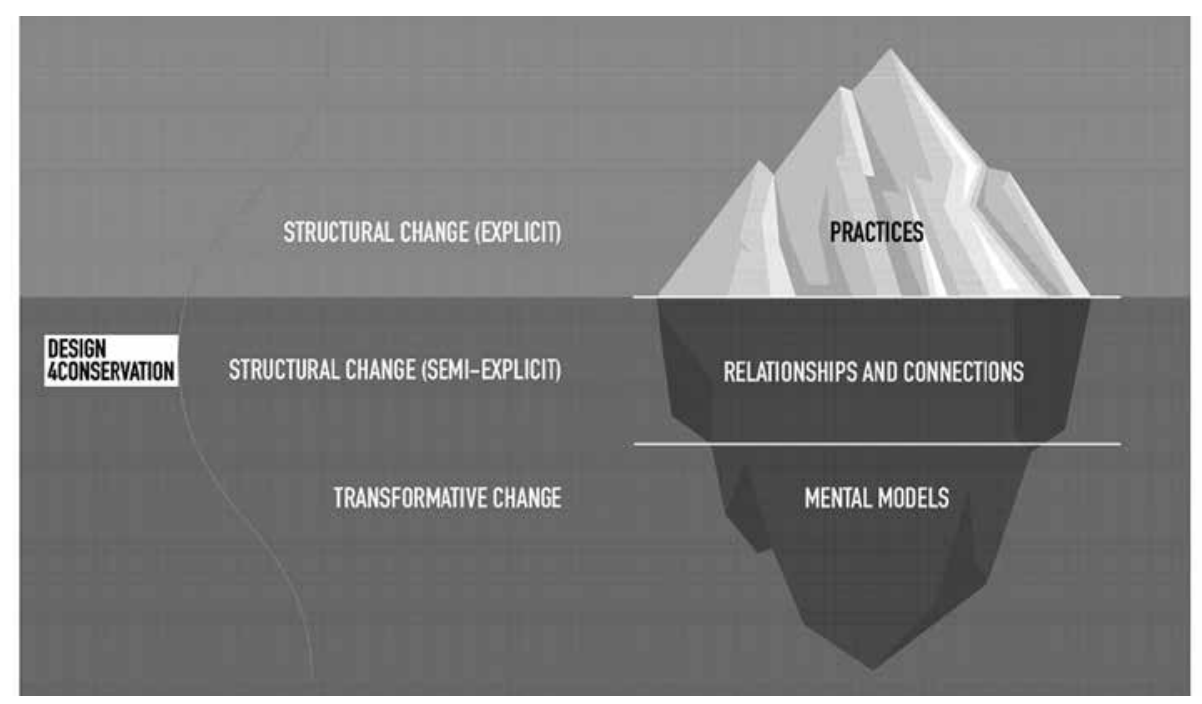

Figure 1. New paradigms of being, relating to each other and doing that operate from foundational levels (mindsets or mental models), through a relational level (interdisciplinarity), and into a practices level (actions). Source: Gabriela Baron, 2020.

The iceberg model has been widely used to discuss the root and visible dimensions of a problem. Figure 1 shows that what is visible above the waterline, the tangible $20 \%$ of a proposed solution, can only be sustainable in time if what lies below the surface, the $80 \%$ of the system, supports the surface actions.

Usually, different methods and initiatives provide siloed solutions at one of these levels. Traditional western approaches to environmental conservation operate at the surface level, offering technical solutions independent from the relational and attitudinal levels. However, this notion is currently being challenged, with an emergence of more solutions that incorporate the relational levels and some that extend all the way to the mindset 
levels. The D4C methodology aims to operate vertically across all three levels and incorporates tools to facilitate this integral, transformative change-making.

\section{Background}

\section{Designerly ways of thinking}

The adoption of specific mindsets has been a critical component for most Human-Centred Design disciplines (Schweitzer et al., 2016), understanding that it is unlikely to "separate the thinking from the doing, or the practice from the practitioner" (Kimbell, 2011). When placing people at the center of a design process, design practitioners are expected to put into place a series of attitudes that will deeply determine the outcome of their work. By the very nature of their professional practice, designers have mastered a set of skills applicable to a broader range of problems (Brown and Katz, 2011). This is why, in the last decade, designers' models and methods for creative problem-solving have been captured and systematized for their implementation by other professionals, not necessarily designers. The use of design methods and models in fields that are not traditionally within the design realm is widely known as Design Thinking.

Design Thinking (DT) can be defined as a process for creative problem solving traditionally used by Designers that "can help us systematically extract, teach, learn and apply these human-centered techniques to solve problems in a creative and innovative way" (Friis Dam \& Siang 2020).

The DT process (and its variations) have become a practical methodology for agile, collaborative innovation in academic, professional, and amateur environments. Large corporations such as Apple, Google, and Samsung have rapidly adopted Design models as drivers to innovation, and Design Thinking is being taught at leading universities worldwide, including d.school, Stanford, Harvard, and MIT.

Design-led innovation is characterized mainly by models structured by divergent and convergent cycles, including;

- the Double Diamond Methodology (Design Council, 2018),

- Design Thinking model by Ideo (IDEO, 2009)

- the Loop, a continuous cycle of observing, reflecting, and making (IBM, 2018).

- the 5 stage-model, it systematizes and identifies the 5 stages/modes expected to carry out in a design project in any innovative problem-solving project (Interaction Design Org. 2020).

All these models are non-linear, exploratory, and iterative in nature (Lockwood and Walton, 2008). In general, these models are better approached with adequate mindsets that, whether explicitly or anecdotally stated, provide guidance on 'ideal' cognitive, attitudinal, and behavioural components to foster creative problem-solving. 
Schweitzer et al. (2016) performed an exhaustive literature review and expert consultation to define the main Design Thinking mindsets and identified 11 themes which have been summarised in Table 1 .

\begin{tabular}{|c|c|}
\hline $\begin{array}{l}\text { Design Thinking } \\
\text { mindsets (themes) }\end{array}$ & Brief explanation \\
\hline $\begin{array}{l}\text { Empathy: Being } \\
\text { empathetic towards } \\
\text { people's needs and } \\
\text { context }\end{array}$ & $\begin{array}{l}\text { DT practitioners have "the ability to see and experience through } \\
\text { another person's eyes, to recognize why people do what they } \\
\text { do". This experience of the DT process is identified as being } \\
\text { one of the defining attributes embodied and enacted by persons } \\
\text { practicing Design Thinking (Berger 2009, Brown 2008, Liedtka } \\
\text { and Ogilvie 2011, Martin 2010). }\end{array}$ \\
\hline $\begin{array}{l}\text { Collaboratively geared } \\
\text { and embracing diversity }\end{array}$ & $\begin{array}{l}\text { DT requires interdisciplinary teams in order to deal with the } \\
\text { multiple facets and interdependencies of innovation projects. } \\
\text { Being collaboratively geared, beyond the usual disciplines, } \\
\text { facilitates a persons' ability to easily integrate with such teams } \\
\text { and to embrace each individual's personality and expertise. } \\
\text { (Jevnaker 2000, Clark and Smith 2010, Burdick and Willis } \\
\text { 2011, Hassi and Laakso 2011). }\end{array}$ \\
\hline $\begin{array}{l}\text { Accepting of } \\
\text { uncertainty and open to } \\
\text { risk }\end{array}$ & $\begin{array}{l}\text { DT practitioners are expected to accept and embrace } \\
\text { uncertainty over-extended periods (Liedtka and Ogilvie 2011, } \\
\text { Hassiand Laakso 2011, Boland and Collopy 2004, Adams et al. } \\
2011 \text {, Kelley and Kelley 2013). They need to make decisions } \\
\text { based on the future potential of a solution over what is already } \\
\text { known to work, "creating something that isn't" (Liedtka and } \\
\text { Ogilvie, 2011:7). }\end{array}$ \\
\hline $\begin{array}{l}\text { Inquisitive and open to } \\
\text { new perspectives and } \\
\text { learning }\end{array}$ & $\begin{array}{l}\text { Inquisitiveness and an appetite for learning are necessary to } \\
\text { understand customer and market context more thoroughly } \\
\text { (Adams et al. 2011, Kelley and Kelley 2013). Discovering new } \\
\text { perspectives by engaging in one's own "intuition, instinct, tacit } \\
\text { knowledge" is the key part of gathering insights from others in } \\
\text { DT projects (Brown, 2009). }\end{array}$ \\
\hline $\begin{array}{l}\text { Mindful of process and } \\
\text { thinking modes }\end{array}$ & $\begin{array}{l}\text { DT practitioners must have awareness of what stage of the } \\
\text { design process the team is engaged in, what behaviours and } \\
\text { goals it may have at any given moment, when a team needs to } \\
\text { be highly generative versus when it needs to converge on a } \\
\text { single solution path-ability to 'know what you know' (Flavell, } \\
\text { 1976). }\end{array}$ \\
\hline Experiential intelligence & $\begin{array}{l}\text { Designers try out ideas by making mock-ups, drawing-up what } \\
\text { thoughts or ideas may look like, building models and creating } \\
\text { something tangible to experiment and test towards a 'better' } \\
\text { answer (Michlewski, 2008). }\end{array}$ \\
\hline
\end{tabular}

Table 1. Main themes in Design Thinking mindsets. Data from Schweitzer et al. (2016). 
While most of these mindsets relate to the operational attitude towards a design project, empathy stands as the fundamental skill that would enable designers to let go of their ego, step outside their preconceptions, understand and correctly interpret other people's needs and desires (Scharme, 2014). Empathy has been recognized as "the foundation of a human-centered design process" (Both and Baggereor, 2010).

But what is the role of empathy when designing for sustainability and conservation purposes?

\section{Reconnecting through Empathy}

A perceived lack of empathy towards both humans and non-human beings is an emerging theme in studies of how human beings relate at an emotional level to the natural environment (Rifkin, 2009). This emotional aspect of empathy has taken importance in different study fields, including environmental psychology, sociology, and philosophy, and it suggests that it is more than a mental model that one can practice and adopt over time. Despite different perspectives, most claim that building empathy within society (towards other people) and with the non-human world, stimulates pro-environmental action (Rifkin 2009, Krznaric 2014).

Empathy as a mindset in Design Thinking has been usually associated to human-human interactions through statements like "empathetic towards people's needs and context" (Schweitzer et al. 2016), and "being open, avoiding being judgmental and being comfortable with people with different backgrounds and opinions" (Carlgren et al. 2016). However, contemporary researchers have started associating empathy to a wider range of multispecies interactions, and often differentiate between two types of empathy: affective and cognitive empathy (Greater Good Science Center, 2020).

Affective empathy refers to the sensations and feelings people get in response to others' emotions; this can include mirroring what that person is feeling, or just feeling stressed when we detect another's fear or anxiety. Affective empathy, as a "sensation" or "feeling" can occur between different species, humans and non-humans (Greater Good Science Center, 2020). Empathy can lead individuals to take the perspective of, and have feelings for, the natural world (Naess, 1990) similar to seeing and experiencing through another person's eyes (Schweitzer et al. 2016). These perceptions have been demonstrated in a range of different studies. In education research, for instance, "using empathy as an imaginative act" has supported a deep understanding of environmental knowledge and enhanced sustainability awareness (Jensen, 2016). Similarly, in public policy, New Zealand and several other governments around the world have recognized the "personhood of elements of the environment" (Morris and Ruru, 2010) and have given legal status to natural elements such as animals, rivers and mountains.

The second type of empathy is called cognitive empathy, or "perspective-taking," and it is defined as an "ability" more than a "feeling". Cognitive empathy refers to our ability to identify and understand other people's emotions (Greater Good Science Center, 2020), it is a skill that can be rationalized, practiced, and mastered over time.

In both cases, empathy plays a crucial role in what we could consider as two opposite ends of the disciplinary spectrum: Anthropocentrism and Deep Ecology. For the anthropocentric 
worldview, where humankind is regarded as the central or most important element of existence, empathy towards future generations is a fundamental aspect of Sustainable Development (Pahl and Bauer, 2013). In contrast, for the Deep Ecology philosophy (Naess, 1990), which regards human life as one of many equal components of a global ecosystem, empathy towards the natural world is inherent. Both approaches agree that empathy can lead to greater engagement with environmental problems and pro-environmental behaviour.

More research is needed to identify the processes by which empathy leads to action, specifically in a design project context. How, in other words, people shift from 'feeling' to 'doing. In recent years, several scholars have been investigating the link between empathy and moral actions, concluding that empathy orients us toward moral action, but it doesn't seem to help much when that action comes at a personal cost (David Brooks, 2011). Jesse Prinz, a philosopher at City University of New York, summarized his research findings this way: "these studies suggest that empathy is not a major player when it comes to moral motivation. Its contribution is negligible in children, modest in adults, and non-existent when costs are significant" (Prinz, 2011).

Paul Bloom (2016), in his recent book, 'Against empathy' illustrated two main reasons for the limits of Empathy to result in compassionate actions. Firstly, he highlighted that empathy could be biased: we tend to be more empathetic towards people who look like us and from the same ethnicity or race, think like us, with similar values and beliefs. Secondly, empathy towards the environment also can be biased, we care more about our own surroundings, community and country compared to places that are far away from where we live and know. For example, it seems easier for us to empathize with particular species, such as dolphins, compared to various critically endangered shark species (Mann and Plummer, 1995). This aspect is well known by designers, where the selection of "flagship species" to visually represent an environmental cause is not aleatory.

Another shortcoming of empathy that Bloom (2016), raises is the misusing of the built-up emotions towards the so-called victims. Feeling the pain of the victim, whether human or part of the natural realm, can create a sense of hatred against the sources which caused the pain. This could result in uncompassionate actions that are neither helpful nor useful. Therefore, he concluded that emotion should not be the moral guide, specifically in decision making in the social context. He proposes to be 'rationally compassionate', meaning to do all analysis required rationally first and then build up compassionate care towards the situation and all the parties involved. Similarly, controversy arises when conservationists choose to protect a particular species (of native birds, in the New Zealand context) over an invasive pest (such as a house cat) by understanding the systemic dynamics of an environment and making rationally compassionate decisions (Mann and Plummer, 1995).

This analysis of the role of empathy has led us to include it as an integral part of the D4C methodology. We understand empathy as much more than a mindset, but as a rationally and emotionally compassionate state of connection with the self, with other humans, and with the natural realm as an indivisible whole. There is an urgent need to include both emotional and cognitive (Sevillano et al. 2007) aspects of empathy in designing for the natural environment. This mind-heart synergy is presented as the central phase of the D4C methodology, and we have named it "re-connect". The reconnection stage is the core of the D4C methodology and should inform all other steps (See figure 2). 


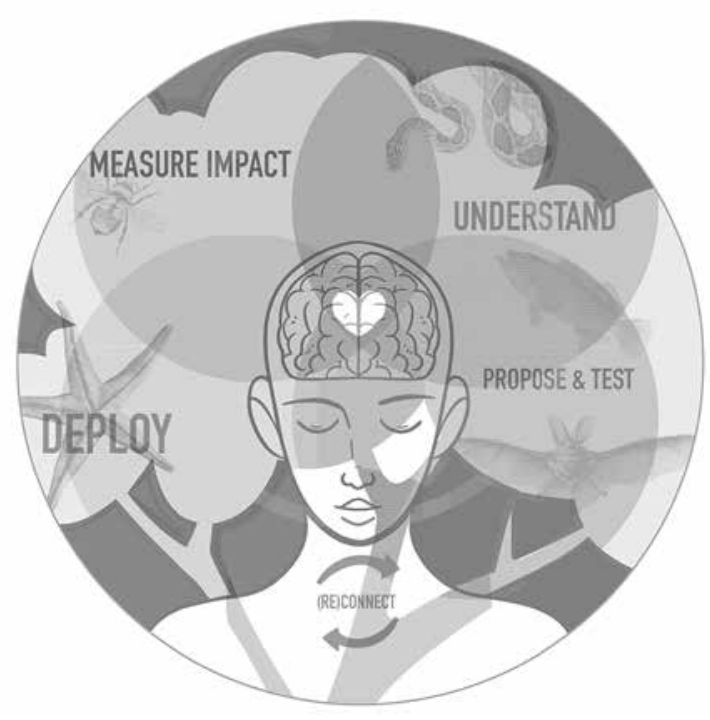

Figure 2. Overview of the D4C methodology steps.

Figure 2 shows an overview of the D4C methodology. Empathy is central to the (re)connect stage, both as an emotional and cognitive connection to ourselves, our community and our land. The reconnect stage informs all other stages of the process.

\section{Designing for the Natural Environment}

The complex, socio-environmental problems that humanity is currently facing have been catalogued as 'wicked problems' (Rittel and Webber, 1973). This term denotes problems for which it is impossible to define optimal solutions because of both uncertainties about future environmental conditions and intractable differences in social values (Shindler \& Cramer, 1999). In 1992, Buchanan published a journal article titled "Wicked problems in Design Thinking" where he argues that designers, by the bridging nature of their practice, have been finding partial solutions to wicked problems all along. Design problems have always been "indeterminate" and "wicked" because design has no special subject matter of its own apart from what a designer conceives it to be: the subject of design is universal in scope.

Because Design Thinking may be applied to any area of human experience, it can play a crucial role in approaching wicked problems. Design is key to "sustaining, developing, and integrating human beings into broader ecological and cultural environments, shaping these environments when desirable and possible or adapting to them when necessary" (Buchanan, 1992). 
But what makes a problem wicked? We propose six descriptive categories to define a wicked problem based on previous analyses made by Rittel and Webber (1973), Buchanan (1992), (Irwin 2011), and Duckett et al. (2016), presented in Figure 3.

\section{What makes a problem WICKED?}

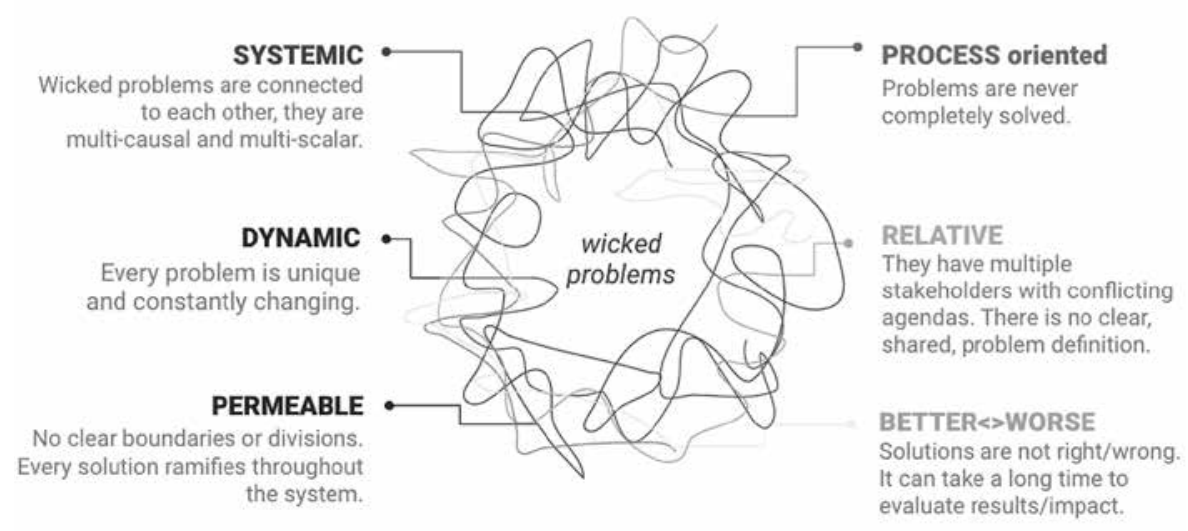

Figure 3. The six characteristics that describe the complex nature of "wicked" problems based on Rittel and Webber (1973), Buchanan, (1992), Irwin (2011), and Duckett et al. (2016). Source: Gabriela Baron, 2020.

Figure 3 shows that wicked problems are systemic, when we acknowledge the interconnectedness of our living systems, there is no single cause to a problem and there are many levels in which this problem affects the whole system. They are also permeable, because they are systemic, any changes to one part of the system will affect the rest of it. They are dynamic, since problems in living systems are constantly fluctuating, and this is why the approaches to dealing with these problems should be process-oriented. Wicked problems are never solved, they do not have a start or a finish point. Finally, wicked problems are relative, their definition depends on the point of view of the observer, and this is also why there are no definite solutions for them.

When dealing with natural systems and problems that arise at the multiple intersections between human-made systems and natural systems, we are dealing with complexities that require mindsets that go beyond the ones defined in DT. 
Traditional designerly mindsets have proven to be effective for achieving innovation in business strategy, customer engagement and marketing, and for the development of new products and services in pursuit of this (Schweitzer et. al, 2006). However, when we examine the designers' own value system and the role it plays in the design process, solutions will be best conceived within a more nature-oriented view (Irwin 2011). Similarly, Jones et al. (2011) have come to the conclusion that "gaining a better understanding of how mental models internally represent complex, dynamic systems and how these representations change over time will allow us to develop mechanisms to enhance effective management and use of natural resources".

Several authors have argued that we require more compelling future-oriented visions to inform and inspire conservation projects in the present (Tonkinwise 2014); that the design solutions in the present need to be informed by longer-term visions of sustainable futures (Dunne and Raby 2013; Manzini and Jegou 2003); and that "Some designers seek new mental modes that facilitate radical and positive environmental change. These new mental modes enable the designers to challenge existing paradigms and envision new ones towards a more sustainable future" (Irwin, 2015).

Following this pressing need for the establishment of new mental models that are coherent and aligned with our natural systems, we have decided to define mindsets as an integral part of the Design for Conservation methodology.

\section{Defining Design for Conservation Mindsets}

When designing for the natural environment, humanity is facing problems that are systemic, dynamic, permeable, process-oriented, and where it is difficult to measure impact. In order to find (partial) solutions to these wicked problems, we need to see possibilities through a new set of mental models that are coherent with the natural realm that we ourselves are part of.

However, traditional DT mindsets are by no means inadequate in D4C. What the D4C methodology proposes is that without letting go of traditional DT mindsets, we can define new mental models that are more in line with our nature as humans and that enable a genuine connection to other people and the natural environment as a whole. These need to be a more accurate representation of beliefs, values, assumptions and expectations of the people that are involved in $\mathrm{D} 4 \mathrm{C}$ projects.

Using bio-inspiration, we have defined seven mental models that are coherent with the principles that govern both natural systems and humans as an integral part of these systems: Honest, Positive, Balanced, Humble, Cyclic, Systemic and Relative (See Figure 4). Below we explain each mindset and also provide actionable recommendations on how to adopt this mindset. 


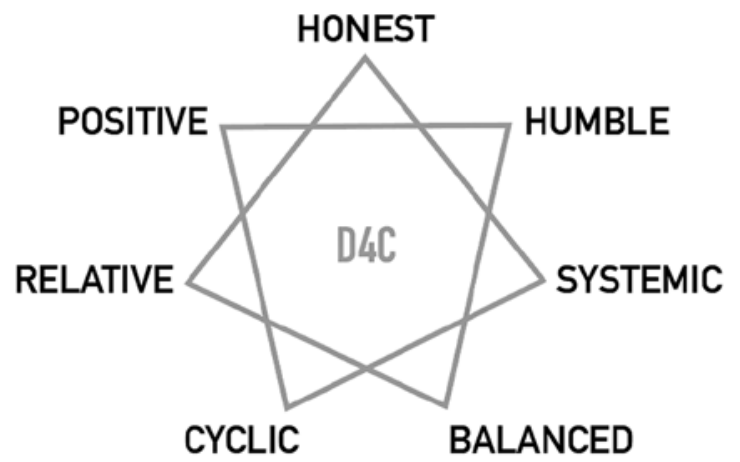

Figure 4. Heptagram diagram that shows the non-hierarchical interconnectedness of the Design for Conservation Mindsets. Source: Gabriela Baron, 2020.

\section{Honest}

In nature, form follows function. This allows organisms to accomplish their goals with the minimum resources (The Biomimicry Institute, 2018).

The honesty that we find in nature should also guide how we practice "self-honesty". Self-honesty encourages vulnerability, openness and awareness, which have been identified as the main principles for building trust between teams (Moldjord et al., 2015).

When people are honest with themselves, they accept their weaknesses and flaws. When self-honest people relate to one another, they appear coherent and fearless, confident by acknowledging their capabilities (Mauri, 2011). The bonds based on self-honesty will be genuine, respectful and strong. People that are self-honest are committed to their core beliefs and are able to align themselves with these.

\begin{tabular}{|l|l|}
\hline D4C Mindsets & Honest \\
\hline Any working team (and the natural realm) & - Be yourself \\
will benefit more from your uniqueness, your & - Create genuine, strong bonds. \\
passions and your spontaneity. & - Always align with your core values. \\
\hline
\end{tabular}

\section{Positive}

Even the most challenging wicked problems have an approachable angle under a positive mindset. A positive mindset is an attitude of people who expect good and desired results. In general, Designers adopt a relentless sense of 'urgent optimism' (Kelley \& Kelley 2013), especially in the face of complex challenges (Beverland and Farrelly, 2007). Positivity within a project is key, since it can help teams convert ideas into reality.

Having a positive mindset can also help teams learn from mistakes and evolve in their projects. Designers will be able to present the proposed outcome, with (almost) always 
guaranteed stage of change, to those not yet convinced of its merit with a high degree of confidence and resolve (Martin, 2010). Whether a team accomplishes their goal or not, the journey will definitely add knowledge and experience for everyone involved.

\begin{tabular}{|l|l|}
\hline D4C Mindsets & Positive \\
\hline $\begin{array}{l}\text { Aim high and expect positive results: every } \\
\text { challenge is an opportunity to learn and grow. }\end{array}$ & $\begin{array}{l}\text { - Cultivate error-friendliness. } \\
\text { - Be grateful and hopeful. } \\
\text { - Use your intent. }\end{array}$ \\
\hline
\end{tabular}

\section{Humble}

When we acknowledge that we are an embedded, small part of a vast system that has a very limited viewpoint, we conduct our projects differently (Manzini, 1994).

We must accept that we cannot entirely control natural systems and acknowledge that our human paradigms, models and data only reflect a tiny part of reality. "The idea of error-friendliness takes in the ideas of production of errors, tolerance of errors, and the 'friendly' cooperation between these two aspects for the exploration of new opportunities. It is in this cooperation where the use of errors is installed; this is an absolutely general characteristic of all living organisms [...] This is a mechanism thanks to which systems can face the future, which is open and unknown (Weizaker, 1988). When we assume that we are controlling a natural system, terrible "unintended" consequences may follow.

Humility relates to the adoption of the beginner's mindset. "It is impossible to learn that which one thinks one already knows" Epictetus ${ }^{4}$ says. When we let ego tell us that we have arrived and figured it all out, it prevents us from learning (Scharmer, 2014).

Wisdom, not cleverness, is the proper aim of all true learning. In the context of innovation, there needs to be a humble balance between fast knowledge and slow wisdom (Calian, 2016). Designers are used to follow 'agile' methodologies using prototypes to test a guess without causing irreversible damage. These methods are intrinsically'error friendly' they test quickly, so that learning from mistakes is cheaper and safer.

\begin{tabular}{|l|l|}
\hline D4C Mindsets & Humble \\
\hline $\begin{array}{l}\text { Trust the earth's old, wise, perfected ways of } \\
\text { doing things. Learn from them, try to imitate } \\
\text { them as much as possible. }\end{array}$ & $\begin{array}{l}\text { - Respect slow wisdom. } \\
\text { - Acknowledge your limited viewpoint. }\end{array}$ \\
\hline
\end{tabular}

\section{Balanced}

Balance can be explained using the Ying and Yang principle. Yin and Yang represent the concept of duality balanced in an indivisible whole, describing how seemingly opposite or contrary forces may actually be complementary, interconnected, and interdependent 
in the natural world, and how they may give rise to each other as they interrelate to one another (Baxter and Sagart, 2014).

Similarly, some authors call these complementary opposites Feminine and Masculine, without relation to gender (Jung, 1973). Yin is the receptive and Yang the active principle. Yin refers to the feminine energies in life, and yang refers to the masculine energies in life. Feminine energy is about being, waiting, caring; while masculine energy is about doing, efficiency and results. Masculine qualities are dominant, strong, independent, assertive, brave, disciplined, rational, etc. Feminine traits are emotional, collaborative, nurturing, vulnerable, caring, humble, intuitive, creative, understanding, etc.

In living systems, achieving a healthy ying-yang balance leads to harmony and equilibrium. In our society, we are far from having achieved any balance of such kind. Looking at these traits, we can easily understand that the current dominant economic and social models are powered by masculine traits and that this lack of balance has led us to the environmental emergency that we find ourselves in. When looking at the feminine, the Yin, it becomes evident why the natural realm is traditionally presented as female, why mother earth is a mother and not a father, and the qualities that we need to foster in order to restore some balance.

\begin{tabular}{|l|l|}
\hline D4C Mindsets & Balanced \\
\hline Seek balance between soft and hard & - Explore alternative knowledge to the main \\
approaches, they are complementary, & scientific paradigms. \\
interconnected, and interdependent in the & - Seek balance within yourself and in your \\
natural world. & methods. \\
& - Remember that the Earth is feminine. \\
\hline
\end{tabular}

\section{Cyclic}

Just like nature is cyclic, humans that are embedded in it are cyclic. Every living system has phases of growth and phases of rest (e.g.: summer and winter, wake and sleep), this is the slow wisdom that enables evolution, where growth is based on quality more than quantity. We must acknowledge that any living system that is growing relentlessly eventually collapses. "There is balance in the ecosystem, then, when the system-environment interaction leads to a stopping of the growth of all the auto-maximalizing entities present in it" (Manzini, 1994).

We must embed circular, regenerative models into your projects from the conception stages. Throughout the D4C methodology, teams can go from "agile to deep" analysis in cycles, iterating and optimizing their understanding, ideas, projects. These cycles are spirals moving forward and they apply to people as they apply to projects (e.g. Build on ideas of others, re-interpret your previous ideas, iterate in order to refine). 


\begin{tabular}{|l|l|}
\hline D4C Mindsets & Cyclic \\
\hline $\begin{array}{l}\text { When we think in cycles, nothing ever is lost, } \\
\text { everything is transformed, just like in the }\end{array}$ & - Problems are never completely solved. \\
natural realm. & - Think in processes, circles and spirals. \\
\hline
\end{tabular}

\section{Systemic}

Nature is systemic. A system is greater than the sum of its parts, as Buckminster Fuller (1963) said. What makes it great are the interactions and relationships between those parts.

Ezio Manzini, a notable thinker in the realms of design and sustainability, returns to the aristotelian idea of Physis in order to characterize nature: "And it is exactly in this continuous dialogue between order, disorder and organization, that we find physis: nature, that shows itself to be unitary, integrated and irreductible in its parts. A nature in which chance and necessity combine in the most unforeseeable ways. A vital nature, in which we are immersed, of which we ourselves are made, and which we ourselves have produced" (Manzini, 1994).

No organism can survive completely in isolation from other living things -human beings included. All living things depend on resources and ecosystem services made available through interconnected webs of relationships that compose the living system that is Earth itself (Biomimicry Institute, 2018).

\begin{tabular}{|l|l|}
\hline D4C Mindsets & Systemic \\
\hline Understand yourself and your projects as & - Start small but never lose sight of the system. \\
living processes, embedded and intertwined & - Plan for intended and unintended \\
within all of the other processes that make up & consequences. \\
a living world. & - Everything is connected. \\
\hline
\end{tabular}

\section{Relative}

In nature, there is no "absolute" frame of reference. Every time you measure, make a statement, or get an insight, it's always in relation to your frame of reference.

In the $\mathrm{D} 4 \mathrm{C}$ approach, participants must consider numerous points of view simultaneously, become comfortable with ambiguity and embrace uncertainty. We must be critical towards any existing paradigm and see the world with fresh eyes, understanding that in wicked problems, everything is relative.

In both biology and design, a strategy that works well to meet a function in one context, might not work in a different setting. We must be prepared to deconstruct and reframe problems continuously.

Critical questioning is most useful when iterating or synthesising information and ideas (Adams et al. 2011) where the DT practitioner questions bias and beliefs or tests the relevance of ideas first, which is also known as the notion of adopting a 'beginners mind' 
(Buchanan 1992, Kelley and Kelley 2013, Goldschmidt and Rodgers 2013, Dorst 2011, Badke-Schaub et al. 2010, Adams et al. 2011, Miller and Moultrie 2013, Michlewski 2008).

\begin{tabular}{|l|l|}
\hline D4C Mindsets & Relative \\
\hline Be open to new perspectives within yourself & - Step into different shoes, hear different \\
and from other species. Unlearn. Challenge & voices. \\
your assumptions. Relearn. Repeat. & - Be curious, run tests. \\
& - Embrace uncertainty, relativity and ambiguity. \\
\hline
\end{tabular}

\section{Discussion and Conclusion}

As the window of time to address environmental issues shrinks, it becomes imperative for communities to quickly develop conservation strategies independently, autonomously, making use of their available resources. Design methodologies can support the achievement of sustainability and conservation goals, by facilitating collaboration, structure, agility, innovation and community engagement. However, for this change to be transformative and resilient, we need to collaborate as an interdisciplinary community, from the mental models level to the practices level.

It is becoming more evident that technical, operative solutions are insufficient in addressing complex challenges that have roots in the social, political and cultural dimensions. Traditional conservation approaches that operate on the practices levels only are being challenged and adapted to a new paradigm of collaboration, interdisciplinarity, and bottom-up empowerment.

Transformative methodologies operate from the lowest level of mental models, through the relational (social) level into the practices level. Therefore, the definition of adequate mental models in the context of change is fundamental to ensuring transformative innovation.

The Design for Conservation methodology proposes a toolkit that will serve as a methodological resource for communities to frame, strategize, design and deploy conservation projects. This methodology can only be complete with the definition of adequate mindsets that participants should adopt in order to engage genuinely with their team and their communities.

Empathy is one of the core abilities related to the practice of Design. In the D4C methodology we have considered empathy as an emotional and cognitive state of genuine connection with ourselves, our communities and the natural environment. This mind- heart synergy is presented as the central phase of the D4C methodology and should inform all other steps.

We have also defined adequate mindsets for undertaking environmental sustainability and conservation-oriented projects. While these mindsets are bio-inspired ${ }^{5}$, they also state general "human" values that are not limited to the D4C Methodology, and their adoption will certainly have benefits that go beyond this practice. We can safely assume that the ap- 
plication of these mindsets could be "universal" and that their conscious adoption would add balance to any project development.

The seven mindsets that we propose are: Honest, Positive, Balanced, Humble, Cyclic, Systemic and Relative (Figure 4). However, this is not meant to be a definitive nor exhaustive list. Hopefully, these seven mindsets create spaces for discussion and debate about alternative futures and new ways of being that are coherent with our true-selves.

\section{Endnotes}

1. Design for Conservation is a methodology under development by Gabriela Nuri Baron. More details at www.design4conservation.com

2. Research on this says that he did not say these exact words, but he did speak along these lines. Interestingly, when he did, he was not speaking abstractly, but speaking of the need for a new ethical perspective arising in and from the human heart... (Sid Kemp, 2020, retrieved from Quora.com) https://www.quora.com/Did-Albert-Einstein-ever-say-writethat-We-cant-solve-problems-by-using-the-same-kind-of-thinking-we-used-when-wecreated-them-If-so-where-and-when-did-he-say-write-so

3. The words mental models and mindsets are used interchangeably throughout this paper. 4. Epictetus was a disabled Roman slave who became the most influential Stoic teacher upon being emancipated. His most famous works are The Enchiridion (AD 125) and Discourses (AD 108).

5. "Bio-inspired" is generally accepted as an umbrella term for design approaches, biomimicry included, that use biology as a resource for solutions. Biomimicry focuses on understanding, learning from, and emulating the strategies used by living things, with the intention of creating designs and technologies that are sustainable. Biomimics can help us to shift our perspective, see design problems and objectives differently, and uncover "new" solutions to difficult problems (Benyus, 1997).

\section{References}

Adams, R. S.; Daly, S. R.; Mann, L. M. \& Dall'Alba, G. (2011). Being a professional: Three lenses into design thinking, acting, and being. Design Studies, 32, 588-607.

Badke-Schaub, P. \& Cardoso, C. (2010). Design thinking: A paradigm on its way from dilution to meaninglessness? Proceedings of the 8th Design Thinking Research Symposium (DTRS8).

Baxter, W. H. \& Sagart, L. (2014). Old Chinese: A New Reconstruction. Oxford: Oxford University Press. ISBN 978-0-19-994537-5.

Benyus, J. M. (1997). Biomimicry: innovation inspired by nature. New York: Morrow.

Berger, W. (2009). How design can transform your life, and even maybe the world. New York: The Penguin Press. 
Beverland, M. \& Farrelly, F. J. (2007). What Does It Mean to Be Design! led Design Management Review, 18, 10-17.

Biomimicry Institute (2018). Nature inspired innovation. Retrieved from www.biomimicry. org on 2 December 2020.

Boland, R. \& Collopy, F. (2004). Managing As Designing. Bibliovault OAI Repository, the University of Chicago Press.

Both, T. and Baggereor, D. (2010). Bootcamp bootleg, Design School Stanford, Palo Alto.

Brooks, D. (2011), The Limits of Empathy. Retrieved from https://www.nytimes.com/2011/ 09/30/opinion/brooks-the-limits-of-empathy.html

Brown, T. (2008). Design thinking. Harvard Business Review, 86, 84-95.

Brown, T. (2009). Change by design, HarperCollins, p. 378.

Brown, T. \& Katz, B. (2011). Change by Design. Journal of Product Innovation Management, 28(3), 381-383. 10.1111/j.1540-5885.2011.00806.x

Bloom, P. (2016). Against Empathy: The Case for Rational Compassion, Ecco Press.

Buckminster Fuller, R. (1963). Operating Manual for Spaceship Earth. (New York: E.P. Dutton \& Co., 1963)

Burdick, A. \& Willis, H. (2011). Digital learning, digital scholarship and design thinking. Design Studies, 32, 546-556.

Buchanan, R. (2009). 'Wicked Problems in Design Thinking. In David Brody and Clark (eds.). Design Studies: A Reader. Oxford; New York: Bloomsbury Academic, 5-21.

Cailan, K. (2016). How Slow Knowledge can save us in the Information Age. The difference between information and wisdom. Retrieved from https://medium.com/@kylecalian/ how-slow-knowledge-can-save-us-in-the-information-age-c8bf70cab57a\#: :text= So $\% 20$ here $\% 20$ is $\% 20$ a $\% 20$ list,context $\% 2$ C $\% 20$ patterns $\% 2$ C $\% 20$ and $\% 20$ connections on 2 December 2020.

Carlgren, L.; Rauth, I. \& Elmquist, M. (2016). Framing Design Thinking: The Concept in Idea and Enactment. Creativity and Innovation Management. 25. 38-57. 10.1111/caim.12153.

Clark, K. \& Smith, R. (2010). Unleashing the power of design thinking. In: Lockwood, T. (ed.) Design Thinking : integrating innovation, customer experience, and brand value I edited by Thomas Lockwood. NY: Allworth Press.

Cox, S. G. (2005). Cox Review of Creativity in Business: building on the UK's strengths. London: HM Treasury.

Craik, K. J. W. (1943). The nature of explanation. University Press, Macmillan.

Cross, N. (2007). 'From a Design Science to a Design Discipline: Understanding Designerly Ways of Knowing and Thinking. In Ralf Michel (ed.). Design Research Now: Essays and Selected Projects. Basel: London: Birkhauser ; Springer [distributor], 41-54.

Dorst, K. (2011). The core of 'design thinking' and its application. Design Studies, 32, 521-532.

Duckett, D.; Feliciano, D.; Martin-Ortega, J. \& Munoz-Rojas, J. (2016). Tackling wicked environmental problems: The discourse and its influence on praxis in Scotland, Landscape and Urban Planning, Volume 154, Pages 44-56, ISSN 0169-2046.

Dunne, A. and Raby, F., (2013). Speculative Everything: Design, Fiction, and Social Dreaming. The MIT Press. 
Design Council, “The Design Process: What is the Double Diamond?” (2018).[Online]. vailable: www.designcouncil.org.uk/news-opinion/design-process-whatdouble-diamond. [Accessed: 04-Aug-2018]

Flavell, J. H. (1976). Metacognitive aspects of problem solving. The Nature of Intelligence, 12, 231-235.

Friis Dam, R. and Siang, T. Y., Interaction Design Org. What is Design Thinking and Why Is It So Popular? Retrieved from https://www.interaction-design.org/literature/article/ what-is-design-thinking-and-why-is-it-so-popular\#: :text=So $\% 2 \mathrm{C} \% 20$ why $\% 20$ call $\% 20$ it\%20Design,our\%20countries\%2C\%20in\%20our\%20lives.|

Goldschmidt, G. \& Rodgers, P. A. (2013). The design thinking approaches of three different groups of designers based on self-reports. Design Studies, 34, 454-471.

Greater Good Science Centre (2020), What is Empaty? Retrieved from https://greatergood. berkeley.edu/topic/empathy/definition\#: :text=Emotion\%20researchers\%20generally \%20define\%20empathy,might\%20be\%20thinking\%20or\%20feeling.

Hassi, L. \& Laakso, M. Conceptions of Design Thinking in the design and management discourses. (2011). Proceedings of the 4th World Conference on Design Research, IASDR.

IBM. (2018). Ready for a new way to work? Enterprise Design Thinking by IBM. Retrieved from: https://www.ibm.com/design/thinking/

IBM (2018) The Loop Understand the present and envision the future in a continuous cycle of observing, reflecting, and making. Retrieved from https:/www.ibm.com/design/ thinking/page/framework/loop

IDEO. User-centered design. Retrieved from http://www.designkit.org/methods

Interaction Design Org. (2020), 'What is Design Thinking?', Retrieved from https://www. interaction-design.org/literature/topics/design-thinking

Irwin, T.; Kossoff, G.; Tonkinwise, C. and Scupelli, P. (2015). Transition Design Overview. Available at https://www.academia.edu/13122242/Transition_Design_Overview [accessed 24 October 2015].

Jensen, S. (2016). Empahty and Imaginaiton in Education for Sustainability. Canadian Journal of Environmental Education.

Jevnaker, B. H. (2000). How design becomes strategic. Design Management Journal (Former Series), 11, 41-47.

Jones, N. A.; Ross, H.; Lynam, T.; Perez, P. and Leitch, A. (2011). Mental models: an interdisciplinary synthesis of theory and methods. Ecology and Society 16(1): 46. [online] URL: http://www. ecologyandsociety.org/vol16/iss1/art46/

Jones, N. A.; Ross, H.; Lynam, T. and Perez, P. (2014). Eliciting mental models: a comparison of interview procedures in the context of natural resource management. Ecology and Society 19(1): 13. http://dx.doi.org/10.5751/ES-06248-190113

Jung, C. G. (1973). Experimental Researches, Collected Works of C.G. Jung, Volume 2. Princeton, NJ: Princeton University Press. ISBN 978-0-691-09764-0. (Routledge: ISBN 978-0-415-08384-3).

Kania, J; Kramer, M, and Senge, P. (2018). The water of systems change. FSG Reimagining Social Change.

Kelley, T. \& Kelley, D. (2013). Creative Confidence: Unleashing the Creative Potential Within Us All, Crown Publishing Group. 
Kumbell, L. (2009). Beyond design thinking: Design-as-practice and designs-in-practice. CRESC Conference, Manchester.

Kimbell, L. (2011). “Rethinking Design Thinking.” Design and Culture, 3(3): 285-306

Krznaric, R. (2014). Empathy: a Handbook for Revolution, Random House, London (2014), Google Scholar.

Liedtka, J. \& Ogilvie, T. (2011). Designing for Growth: A Design Thinking Tool Kit for Managers, Columbia Univ Press.

Lockwood, T. \& Walton, T. (2008). Building Design Strategy: Using Design to Achieve Key Business Objectives. New York, NY: Allworth Press.

Naess, A. (1990). Outline of an Ecosophy. Translated and revised by David Rothenberg. (Cambridge and New York: Cambridge University Press, 1989. xiii +233 pp., figures, notes, bibliography, index).

Mann, Ch. C. and Plummer, M. L. (1996). Noah's Choice: the Future of Endangered Species. Knopf.

Manzini, E. (1994). Physis and design. Interaction between nature and culture. Temes de disseny; Núm.: 10 Edició català-castellà-anglès.

Manzini, E. and Jégou, F. (2003). Sustainable Everyday. Scenarios of Urban Life. Milan: Edizioni Ambiente.

Martin, R. L. (2010). Design thinking: achieving insights via the "knowledge funnel". Strategy \& Leadership, 38, 37-41.

Mauri, M. (2011). Self-respect and Honesty. Filozofia 66, 2011, No 1, p. 74.

Michlewski, K. (2008). Uncovering design attitude: Inside the culture of designers. Organization Studies, 29, 373-392.

Miller, K. \& Moultrie, J. (2013). Understanding the Skills of Design Leaders. Design Management Journal, 8, 35-51

Moldjord, Ch. \& Iversen, A. (2015). Developing vulnerability trust in temporary high performance teams. Team Performance Management. 21.10.1108/TPM-08-2014-0050.

Morris, J. \& Ruru, J. (2010). Giving Voice to rivers: Legal Personality as a vehicle for recognising indigenous peoples'relationships? Australian Indigenous Law Review, 14(2), 49-62. Retrieved December 21, 2020, from http://www.jstor.org/stable/26423181

Pahl, S. \& Bauer, J. (2013). Environment and Behavior - journals.sagepub.com

Paton, B. \& Dorst, K. (2011). Briefing and reframing: A situated practice. Design Studies, 32, 573-587.

Prinz, J. (2011). Is empathy necessary for morality? In Empathy: Philosophical and Psychological Perspectives (Coplan, A. and Goldie, P., eds), pp. 211-229, Oxford University Press

Rifkin, J. (2009). The empathic civilization: The race to global consciousness in a world in crisis. Tarcher/Penguin Group.

Rittel, H. W. J. and Webber, M. M. (1973). Dilemmas in a general theory of planning. Policy Sci 4, 155-169. https://doi.org/10.1007/BF01405730

Sevillano, V.; Aragones, J. \& Schultz, P. (2007). Perspective Taking, Environmental Concern, and the Moderating Role of Dispositional Empathy. Environment and Behavior. 39. 685705. $10.1177 / 0013916506292334$. 
Scharmer, O. (2014). From Ego-System to Eco-System Economies. Acumen Social Impact Analysis course reading materials. Retrieved from https://www.plusacumen.org/courses/ social-impact-analysis

Schweitzer, J.; Groeger, L. \& Sobel, L. (2016). The Design thinking mindset: an assessment of what we know and what we see in practice. Journal of design, business \& society, 2(1), 71-94. https://doi.org/10.1386/dbs.2.1.71_1

Schweitzer, J.; Groeger, L. \& Sobel, L. (2015). Innovation and design thinking mindsets, Conference: Design for Business: Research Conference At: Melbourne, Australia, Journal of Design Business \& Society 2(1)-10.1386/dbs.2.1.71_1

Shindler, B. \& Cramer, L. A. (1999). Shifting public values for forest management: Making sense of wicked problems. Western Journal of Applied Forestry, 14, 28-34.

Tonkinwise, C. (2014). Design Studies - What is it Good For?. Design and Culture. 6. 5-43. $10.2752 / 175470814 X 13823675225036$.

Weizaker, E. \& Von, C. (1988). «Come vivere con gli errori. IIvalore evolutivo degli errori», in Ceruti, M. and Laszlo, E., 1998.

Google Ventures, the Design Sprint. Retrieved from https://www.gv.com/sprint/

Resumen: Nuestro planeta se enfrenta actualmente a un estado de emergencia sin precedentes por el agotamiento ambiental que ha traído consecuencias como la pérdida de biodiversidad, el cambio climático y el aumento del nivel del mar. Estos desafíos globales y urgentes requieren nuevos paradigmas de ser, relacionarse entre sí y hacer que operen desde un nivel fundacional (modelos mentales), a través de un nivel relacional (conexiones sociales, interdisciplinariedad) y en un nivel de práctica (soluciones técnicas).

Design for Conservation (D4C) es un conjunto de herramientas metodológicas que los grupos de conservación del medio ambiente pueden utilizar para maximizar los resultados de la innovación y garantizar un cambio transformador, sostenible y eficaz. En este artículo, presentamos la justificación detrás de las mentalidades que pretenden establecer actitudes fundamentales al seguir un enfoque D4C. También discutimos el papel de la empatía, que es un aspecto fundamental del enfoque de Design Thinking y también es central para la metodología D4C como la principal habilidad para la etapa de reconexión. Los modelos mentales nos ayudan a simplificar la complejidad, comprender por qué consideramos algunas cosas más relevantes que otras e influir en nuestras decisiones. En general, la mentalidad de los diseñadores contemporáneos promueve la apertura y una actitud positiva a través de la empatía, la colaboración, la creatividad, la facilidad para cometer errores, la iteración, la ambigüedad, entre otros. Si bien estas mentalidades han demostrado ser muy útiles en un contexto liderado por el mercado, son insuficientes cuando se diseñan con fines de sostenibilidad y conservación del medio ambiente. El diseño para la conservación requiere un cambio sistémico radical que desafíe las nociones actuales de valor, éxito, salud y bienestar, que no se pueden lograr siguiendo modelos mentales dirigidos por el mercado. 
Por lo tanto, establecimos la siguiente hipótesis: "mediante el uso de la bioinspiración, podemos identificar los principios generales que rigen tanto a las personas como a los sistemas naturales y utilizarlos como base para definir modelos mentales". El resultado de este análisis llevó a la definición de 7 modelos mentales interconectados que consideran al ser humano como parte de un ecosistema complejo: Honesto, Positivo, Humilde, Equilibrado, Relativo, Sistémico y Cíclico.

Palabras clave: Mentalidades - Modelos mentales - Diseño para la conservación - D4C Diseño para la sostenibilidad - Bio-mimetismo - Cambio transformador - Pensamiento sistémico - Diseño regenerativo.

Resumo: Nosso planeta está atualmente enfrentando um estado de emergência sem precedentes em relação ao esgotamento ambiental que trouxe consequências como perda de biodiversidade, mudanças climáticas e aumento do nível do mar. Esses desafios urgentes e globais exigem novos paradigmas de ser, relacionar-se e fazer que operem desde um nível fundacional (modelos mentais), por meio de um nível relacional (conexões sociais, interdisciplinaridade) e até um nível de prática (soluções técnicas).

Design for Conservation (D4C) é um conjunto de ferramentas metodológicas que grupos de preservação ambiental podem usar para maximizar os resultados da inovação e garantir mudanças eficazes, sustentáveis e transformadoras. Neste artigo, apresentamos a lógica por trás das mentalidades que pretendem definir atitudes fundamentais ao seguir uma abordagem D4C. Também discutimos o papel da empatia, que é um aspecto fundamental da abordagem do Design Thinking e também é central para a metodologia D4C como a principal habilidade para a fase de reconexão.

Os modelos mentais nos ajudam a simplificar a complexidade, entender por que consideramos algumas coisas mais relevantes do que outras e influenciar nossas decisões. Em geral, as mentalidades dos designers contemporâneos promovem a abertura e uma atitude positiva por meio de empatia, colaboração, criatividade, facilidade de erro, iteração, ambigüidade, entre outros. Embora essas mentalidades tenham se mostrado muito úteis em um contexto liderado pelo mercado, elas são insuficientes ao projetar para fins de sustentabilidade e conservação ambiental. Design for Conservation requer uma mudança sistêmica radical que desafia as noções atuais de valor, sucesso, saúde e bem-estar, que não podem ser alcançadas seguindo modelos mentais liderados pelo mercado.

Portanto, estabelecemos a seguinte hipótese: "por meio do uso da bioinspiração, podemos identificar princípios gerais que regem as pessoas e os sistemas naturais e usá-los como base para a definição de modelos mentais". O resultado dessa análise levou à definição de 7 modelos mentais interconectados que consideram os humanos como parte de um ecossistema complexo: Honesto, Positivo, Humilde, Equilibrado, Relativo, Sistêmico e Cíclico.

Palavras chave: Mindsets - Mental Models - Design for Conservation - D4C - Design for Sustainability - Biomimetismo - Mudança transformativa - Pensamento sistémico - Design regenerativo. 